\title{
Partial remission phase of diabetes in children younger than age 10 years
}

\author{
B Jan Muhammad, Peter G F Swift, Neil T Raymond, Johannes L Botha
}

\begin{abstract}
There is renewed interest in the phase of partial remission in recently diagnosed diabetes because of the potential for pharmacological and immune intervention to preserve $\beta$ cell function. 95 children younger than 10 years were investigated to assess the influence of age, sex, diabetic ketoacidosis (DKA), admission at diagnosis, and ethnicity on the frequency of remission and insulin requirements during the first two years after diagnosis. Partial remission was defined as a requirement of insulin $<0.5 \mathrm{U} / \mathrm{kg}$ body weight/day. There was partial remission in 41 patients, with no differences for children aged 2-4 years and those aged 5-9 years. None of the five children aged $<2$ years remitted. Forty five of 95 children were admitted to hospital at diagnosis, of whom 26 of 45 had DKA (blood pH < 7.25). In this number of children we were unable to show a statistical difference in the rate of remission with respect to DKA, admission to hospital at diagnosis, sex, or South Asian ethnic background. There were no differences in insulin requirements between the different groups by the end of two years and at that time seven of the children required insulin $<0.5 \mathrm{U} / \mathrm{kg} / \mathrm{day}$. The results suggest that even in preschool children there is potential for attempting to preserve $\beta$ cell function.

(Arch Dis Child 1999;80:367-369)
\end{abstract}

Keywords: diabetes; remission phase; age

Despite its acute clinical onset, type 1 insulin dependent diabetes mellitus (IDDM) develops as the culmination of a prolonged preclinical phase of progressive destruction of the pancreatic islet cells. ${ }^{1}$ After diagnosis a large proportion of recently diagnosed children and adults with IDDM pass into a phase of partial remission, ${ }^{2}$ characterised by continuation of endogenous insulin secretion, reduced exogenous insulin requirement, and good metabolic control. ${ }^{3-5}$

There is renewed interest in remission, or spontaneous $\beta$ cell recovery, because it has important implications in terms of potential pharmacological intervention and immunomodulation. ${ }^{6}$ Moreover, it has been suggested that admitting children to hospital at diagnosis (and intermittently thereafter) to initiate intensive intravenous insulin treatment might induce a longer remission phase. ${ }^{78}$ This suggestion is linked to the hypothesis that insulin administered before clinical diagnosis might prevent or delay the onset of IDDM. ${ }^{9}$ It is also believed that the preschool child with diabetes is less likely than older children to demonstrate complete or partial remission, ${ }^{10}{ }^{11}$ based on the premise that younger children are more likely to present with ketoacidosis, and are considered to have more $\beta$ cell failure, with a more aggressive autoimmune disorder. ${ }^{12} 13$

The aim of our study was to assess the frequency of partial remission in younger children, particularly because of the potential to sustain the remission phase and thus attain better long term metabolic control.

Study population and methods

We reviewed notes on 110 children diagnosed with IDDM under the age of 10 years during the years 1981-91 who had been notified to the Leicestershire Diabetes Register. We abstracted data for the first two years after diagnosis at $1,3,6,12,18$, and 24 months, recording height, weight, insulin requirement, glycated haemoglobin $\left(\mathrm{HbA}_{1}\right)$ concentrations, length of history of symptoms, ethnic origin (particularly children of Indian subcontinental South Asian extraction), duration of admission to hospital, and presence of diabetic ketoacidosis (DKA) at diagnosis.

We defined partial remission as insulin requirement $<0.5 \mathrm{U} / \mathrm{kg} / \mathrm{day}$, and $\mathrm{DKA}$ as blood $\mathrm{pH}<7.25$.

\section{STATISTICS}

We analysed data using the SAS statistical software package, calculating proportions, means, Fischer's exact tests, and $\chi^{2}$ tests of independence as appropriate. The confidence interval analysis (CIA) software was used to estimate 95\% confidence limits for proportions and their differences. ${ }^{14}$

We compared differences in insulin requirements between subgroups over the study period by the method of summary measures. For each child we calculated the area under the curve for insulin requirement over time using the trapezium rule and standardised the result by dividing by the study period. ${ }^{15}$ We then compared these summary measures using the Student's $t$ test or the Mann-Whitney U test as appropriate.

\section{Results}

Of 110 patients potentially available for study, we included $95(86.3 \%)$. We excluded 15 children because hospital records were not available for six, four had moved from Leicestershire, and five had moved into Leicestershire after the diagnosis. All 95 patients received insulin at diagnosis and have continued to do so. 
Table 1 Patient characteristics, remission details, and 95\% confidence intervals (CI) for differences

\begin{tabular}{|c|c|c|c|}
\hline & Total & $\begin{array}{l}\text { Partial } \\
\text { remission }\end{array}$ & $\begin{array}{l}\% \text { Difference } \\
(95 \% \text { CI) }\end{array}$ \\
\hline All patients & 95 & 41 & (33 to 54 ) \\
\hline \multicolumn{4}{|l|}{ Sex } \\
\hline Boys & 48 & 23 & \multirow{2}{*}{$10 \%(-10$ to 29$)$} \\
\hline Girls & 47 & 18 & \\
\hline \multicolumn{4}{|l|}{ Age at diagnosis } \\
\hline$<2$ years & 5 & 0 & \multirow{3}{*}{$2 \%(-20$ to 23$)$} \\
\hline $0-4$ years & 31 & 13 & \\
\hline 5 to $<10$ years & 64 & 28 & \\
\hline \multicolumn{4}{|c|}{ Hospital admission at diagnosis } \\
\hline Admitted & 45 & 18 & \multirow[t]{2}{*}{$8 \%(-12$ to 28$)$} \\
\hline Not admitted & 50 & 23 & \\
\hline \multicolumn{4}{|l|}{ DKA at diagnosis } \\
\hline DKA & 29 & 9 & \multirow[t]{2}{*}{$18 \%(-3$ to 39$)$} \\
\hline No DKA & $65^{\star}$ & 32 & \\
\hline \multicolumn{4}{|l|}{ Ethnic group } \\
\hline South Asian & 11 & 3 & \multirow{2}{*}{$18 \%(-10$ to 46$)$} \\
\hline White & 84 & 38 & \\
\hline
\end{tabular}

*One missing datapoint.

DKA, diabetic ketoacidosis.

Table 1 describes the initial characteristics and subgroups of patients at entry and summarises the remission results. A total of 41 patients showed some period of partial remission during their first 24 months. We observed similar remission rates in those aged $2-3,4-5$, 6-7, and 8-9 years at diagnosis. None of the five children aged less than 2 years at diagnosis showed partial remission (three of these were admitted to hospital with DKA). More boys than girls and more white than South Asian children showed partial remission, but differences were not significant (sex: $\chi^{2}=0.8961 \mathrm{df}$, $\mathrm{p}=0.33$; ethnicity: Fischer's exact test (two tailed), $\mathrm{p}=0.34$ ).

Fewer children presenting with DKA and admitted to hospital had a remission than those admitted with no DKA or those not admitted, but these differences were not significant $\left(\chi^{2}=3.022 \mathrm{df}, \mathrm{p}=0.22\right)$.

At three months after diagnosis, 29 of the cohort were in remission (about one third each of children $<5$ years at diagnosis and of those aged 5-9 years). By 12 months these figures had fallen to 4 of 36 and 11 of 64 in the younger and older age groups, respectively; by 24 months these figures had fallen further to 1 and 6 , respectively. Throughout the two years the mean insulin requirement was less for those diagnosed aged 5-9 years compared with the

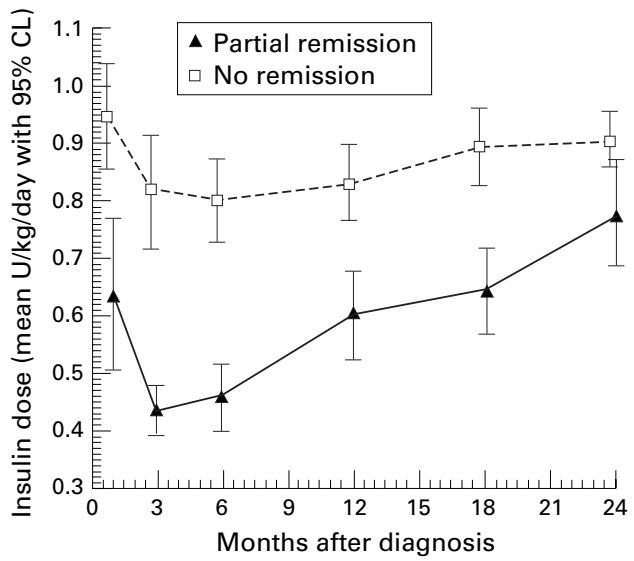

Figure 1 Mean insulin requirement over time with 95\% confidence limits (CL), by observed partial remission. younger age group but the differences were not significant $(p=0.13)$ and mean insulin requirement for boys was $\sim 8 \%$ lower than for girls (not significant, $\mathrm{p}=0.14$ ). For children showing any period of remission the insulin requirements were significantly lower from the first data collection point at one month through to 24 months compared with children not showing remission (fig $1 ; \mathrm{p}<0.01$ ).

There were insufficient data on glycated haemoglobin to relate this to age groups and insulin dosage.

\section{Discussion}

We found statistically similar percentages of children showing partial remission in 2 year age bands from ages 2 to 10 years. However, two years after diagnosis, the exogenous insulin requirement was not significantly different between groups when related to previous remission, age, ethnicity, sex, admission at diagnosis, and initial DKA. No child diagnosed under the age of 2 years remitted and their insulin dosage over the two years was higher than older children.

Estimates of the incidence of remission in IDDM have varied widely, partly reflecting the use of different definitions. Drash described a large cohort in the age group $0-15$ years using the same definition (insulin dosage $<0.5 \mathrm{U} / \mathrm{kg} /$ day) and found that $70 \%$ partially remitted, and that remission occurred more often in older children, in boys, and in those not presenting with severe ketoacidosis. ${ }^{10} \mathrm{He}$ noted, as we did, a lower (10\%) insulin requirement in boys.

In another large cohort (using the same definition), the remission rate at three months was $59 \%$ and at one year $36 \%$, the remission period being identical in children diagnosed at $<5$, $5-10$, or $10-15$ years of age. ${ }^{16}$

Applying a different definition-the fall in insulin requirement of at least 33\% from dose at discharge from hospital-earlier small UK studies quoted $15-40 \%$ of remissions in various age groups..$^{17} 18$

The major criticism of these clinical definitions is that they do not estimate the physiological basis of remission, namely endogenous insulin secretion, or the outcome in terms of glycated haemoglobin. Agner et al showed that C-peptide concentrations were higher and glycated haemoglobin concentrations were lower in the third of their patients under the age of 16 years who remitted. ${ }^{4}$ Unfortunately, in our cohort glycated haemoglobin measurements in the first 12 months after diagnosis were insufficient to provide valid data but we note that the group of children remitting had significantly lower insulin requirements within the first weeks after diagnosis (fig 1) and this is associated with clinically excellent glycaemic control. This is important because recent evidence from large multicentre studies suggests that good diabetic control achieved soon after diagnosis is more likely to be sustained (T Danne, unpublished data, 1998). ${ }^{19}$ The reverse is often observed-that poor control early on in diabetes is more likely to be associated with continuing unsatisfactory control thereafter. 
Extensive clinical, genetic, and biochemical studies of the early months of diabetes after clinical onset in Finland have shown that in children diagnosed under the age of 2 years, DKA is more likely, partial remission is uncommon, and serum C-peptide concentrations are low. ${ }^{13}$ Our finding of no remission and higher insulin requirements in the infants $<2$ years old is consistent with this. The intensity of $\beta$ cell destruction is associated with genetic determinants, particularly HLA DR3/DR $4^{12}$ or DQB1 0302/0201 heterozygosity. ${ }^{20}$ Thus, the continuation of residual $\beta$ cell function and partial remission may vary between different genetic subgroups in different countries. ${ }^{21}$

Perhaps of greater clinical importance in the UK and elsewhere is the fact that care of newly diagnosed children with IDDM is shifting towards domiciliary and community management. ${ }^{22} 23$ Therefore, the suggestion that intensive insulin treatment at disease onset might prolong and deepen the remission phase ${ }^{8}$ causes some concern, especially as recent data from the diabetes control and complications trial (DCCT) tends to support this idea. ${ }^{19}$ Our results do not contribute to this important debate partly because we were unable to document the relation between insulin dose, residual $\beta$ cell function, and metabolic control. Therefore, it remains to be seen whether exogenous insulin before onset, ${ }^{9}$ or intensive insulin treatment afterwards, ${ }^{78}{ }^{24}$ can appreciably preserve $\beta$ cell function and alter the long term clinical outcome of children with diabetes.

We have shown that in children given conventional insulin treatment and often managed initially out of hospital, over $40 \%$ of preschool and older children go into a transient phase of partial remission. This is a higher figure than in some reports, but significantly lower than in others, and it will be important to test prospectively whether the differences are a result of genetic or pathophysiological dissimilarities, or whether more intensive insulin treatment at diagnosis might prolong the remission phase.

The partial remission phase should be reflected by glycated haemoglobin concentrations close to normal, and careful monitoring of these concentrations during the first two years after diagnosis might provide a useful audit of the success or failure of diabetes management in children.

We conclude therefore that the "honeymoon period" with continuation of endogenous insulin secretion continues to provide a window of opportunity for the evaluation of insulin treatment and potential new treatments in an attempt to preserve pancreatic $\beta$ cell function and to establish a pattern of optimal metabolic control.

1 Tarn AC, Smith CP, Spencer KM, Bottazzo GF, Gale EAM. Type 1 (insulin dependent) diabetes: a disease of slow clinical onset? BMF 1987;294:342-5.

2 Baker L, Kaye R, Root AW. The early partial remission of juvenile diabetes mellitus. $\mathcal{F}$ Pediatr 1967;71:825-31.

3 Ludvigsson J, Heding LG. $\beta$-cell function in children with diabetes. Diabetes 1978;27(suppl):230-4.

4 Agner T, Damm P, Binder C. Remission in IDDM: prospective study of basal C-peptide and insulin dose in 268 consecutive patients. Diabetes Care 1987;10:164-9.

5 Knip M, Sakkinen A, Huttunen N-P, et al. Post-initial Knip M, Sakkinen A, Huttunen N-P, et al. Post-initial
remission in diabetic children-an analysis of 178 cases. Acta Paediatr Scand 1982;71:901-8.

6 Bingley PJ, Gale EAM. Prevention of IDDM. In: Kelnar, $\mathrm{CJH}$, ed. Childhood and adolescent diabetes. London: Chapman and Hall, 1995:503-18.

7 Mirouze J, Selam JL, Pham TC, Mendoza E, Orsetti A. Sustained insulin induced remissions of juvenile diabetes by means of an external artificial pancreas. Diabetologia 1978;14:223-7.

8 Shah SC, Malone JI, Simpson NE. A randomised trial of intensive insulin therapy in newly diagnosed insulin dependent diabetes mellitus. $N$ Engl f Med 1989;320:550-4.

9 Keller RJ, Eisenbarth GS, Jackson RS. Insulin prophylaxis in individuals at high risk of type 1 diabetes. Lancet 1993;341:927-8.

10 Drash AL. Clinical characteristics, presentation and initial clinical course. In: Clinical care of the diabetic child. Chicago: clinical course. In: Clinical care of the diabetic chilc
Year Book Medical Publishers, 1987:33-49.

11 Travis LB, Brouhard BH, Shreimer B. The child with diabetes less than 3 years old. In: Travis LB, Brouhard BH, eds. Diabetes in children and adolescents. Philadelphia: WB Saunders, 1987:187-92.

2 Knip M, Ilonen J, Mustonen A, Akerblom HK. Evidence of an accelerated $\beta$-cell destruction in HLA-DW3/DW4 heterozygous children with type 1 (insulin dependent) diabetes. Diabetologia 1986;29:347-51.

13 Komulainen J, Lounamaa R, Knip M, Kaprio EA, Akerblom HK. Ketacidosis at the diagnosis of type 1 (insulin dependent) diabetes is related to poor residual $\beta$-cell function. Arch Dis Child 1996;75:410-15.

14 Gardner MJ, Gardner SB, Winter P. Confidence interval analysis (CIA), version 1.2. London: BMJ Publishing Group, 1991 .

15 Matthews JNS, Altman DG, Campbell MJ, Royston P. Analysis of serial measurements in medical research. BMf
1990;300:230-5.

16 Holl RW, Hecker W, Bartus B, Teller WM, Heinze E. Remission phase in 713 children with type 1 diabetes mellitus. Effects of age, sex and initial therapy [abstract]. $\mathcal{f}$ Pediatr Endocrinol Metab 1995;8(suppl):221.

17 Jefferson IG, Smith MA, Baum JD. Insulin dependent diabetes in under 5 year olds. Arch Dis Child 1985;60:1144 8.

18 Craig JO. The course of childhood diabetes. In: Apley J, ed. Childhood diabetes and its management, 1 st ed. London: Butterworths, 1977:170-85.

19 Diabetes Control and Complications Trial Research Group. Effect of intensive therapy on residual $\beta$-cell function in Effect of intensive therapy on residual $\beta$-cell function in
patients with type 1 diabetes in the DCCT. Ann Intern Med patients with type 1

20 Veijola R, Knip M, Reijonen H, Vahasalo P, Puuka R, Ilonen J. Effect of genetic risk load defined by HLA-DQB1 polymorphism on clinical characteristics of IDDM in children. Eur F Clin Invest 1995;25:106-12.

21 Daneman D, Knip M. Kaar M-L, Sochett E. Comparison of children with type 1 (insulin dependent) diabetes in northern Finland and southern Ontario: differences at disease onset. Diab Res 1990;14:123-6.

22 Swift PGF. Childhood diabetes in the community. In: David, TJ, ed. Recent advances in paediatrics, Vol. 14. Edinburgh: Churchill Livingstone, 1995:15-35.

23 Charron-Prochownik D, Siminerio L, Maihle T, Songer T. Outpatient versus inpatient care of children newly diagnosed with IDDM. Diabetes Care 1997;20:657-60.

24 Schnell O, Eisfelder B, Standl E, Ziegler A-G. High dose intravenous insulin infusion versus intensive insulin treatintravenous insulin infusion versus intensive insulin treat-
ment in newly diagnosed IDDM. Diabetes 1997;46:160711 